\title{
O MERCADO DE TERRAS NOS CERRADOS PIAUIANSES: MODERNIZAÇÃO E EXCLUSÃO
}

\section{EL MERCADO DE TIERRAS EN LOS CERRADOS PIAUIENSES: MODERNIZACIÓN Y EXCLUSIÓN}

\section{THE LAND MARKET IN THE PIAUIENSES CERRADOS: MODERNIZATION AND EXCLUSION}

Vicente Eudes Lemos Alves Professor do Departamento de Geografia, do Instituto de Geociências (IG), Universidade Estadual de Campinas (UNICAMP)

Resumo: O presente artigo discute a formação do mercado de terras nos cerrados piauienses a partir do avanço da modernização agrícola na região. Embora a consolidadção desse mercado tenha ocorrido nos anos 1990, é um fenômeno que se inicia na década de 1970, quando os primeiros investidores adquiriram terras no sul do Piauí para o desenvolvimento de projetos de modernização agropecuária e de reflorestamentos, financiados com recursos públicos da Sudene. Nesse período, ocorreu também o aumento da apropriação privada de maneira irregular das terras devolutas, através da grilagem, sobretudo, das localizadas nos denominados platôs planos dos Gerais. A privatização, a valorização e a intensificação da especulação imobiliária dessas áreas trouxeram importantes impactos para as comunidades camponesas locais, na medida em que houve uma substancial redução do uso comunitário e a expulsão das populações posseiras moradoras nos baixões. Neste sentido, o processo de modernização em curso dos cerrados piauienses se revela um fenômeno excludente para a maioria de sua população.

Palavras-chave: Mercado de terras, Modernização agrícola, cerrados piauienses, exclusão

Resumen: El presente artículo discute la formación del mercado de tierras en los cerrados piauienses a partir del avance de la modernización agricola en la región. Apesar de que la consolidación de este proceso ocurrió en los años 1990, es un fenómeno que se inició en la década de 1970, cuando los primeros inversores adquirieron tierras en el sur de Piauí para el desarrollo de proyectos de modernización 
agropecuaria e de reflorestación, financiados con recursos públicos de la Sudene. En este período, ocurrió también el aumento de la apropiación privada de las tierras devolutas de manera irregular, através de la grilagem, sobretodo, de las tierras situadas en los denominados platos planos de los Gerais. La privatización, la valorización y la intensificación de la especulación inmobiliaria en esas áreas trajeron una substancial reducción del uso comunitario y la expulsión de las poblaciones posseras habitantes en las áreas bajas. En este sentido, el proceso de modernización en curso de los cerrados piauienses mostraron un fenómeno excludente para la mayoría de su población.

Palabras clave: mercado de tierras, modernización agricola, cerrados piauienses, exclusión

\begin{abstract}
The current article discuss the creation of the land market in the cerrados piauienses from the advances of its regional modernization. Although the consolidation of that market occured in the $90^{\text {th }}$ decade, it is a phenomenon that begun in the $70^{\text {th }}$, when former investors bought lands in the south of Piaui Estate for the development of projects to modernize the farming and reforestation, funding with public resources of Sudene. During this period, also occurred an increase of the of irregular privative appropriation of remise lands, through by grilagem, moreover, in regions located in plain platos of the Gerais region. The privatization, the valorization and the intensification of real state market speculation in those regions brought important impacts for the farmer local communities, as an essential reduction of use social communitarian and the expulsion of local population that lived in baixões happened. Therein, the modernization process in course of cerrados piauienses is an excluding phenomenon for the most of its population.
\end{abstract}

Keywords: land market, agriculture modernization, cerrados piauienses, exclusion

\title{
Introdução
}

O sul do Piauí, localizado nos cerrados nordestinos, participa, nas últimas três décadas, de importantes transformações espaciais. A recente instalação de novos atores, especialmente de empresas hegemônicas e de grandes agricultores 
agropecuários, confirma aquela sub-região dos cerrados como integrante de uma nova lógica de reprodução do capital. As manifestações de mudanças aparecem tanto no urbano quanto no campo. No primeiro, observa-se o surgimento de um conjunto de cidades no sul do Piauí que cresce com a presença do agronegócio, como Uruçui e Bom Jesus. Nestas, a economia adquire força com as atividades voltadas para atender às demandas do campo, destacando-se comércios e serviços especializados destinados à agricultura moderna (lojas de maquinários, de sementes e de defensivos, escritórios de consultorias agropecuárias, etc.), mas também ganham destaque as atividades direcionadas diretamente ao consumo da população (lojas de vestuário, de eletrodomésticos, de serviços de educação, de telecomunicações, etc). Essas atividades atraem um grande contingente de migrantes de várias partes do Brasil e estrangeiros em busca de trabalho e/ou de investimentos diante das oportunidades surgidas com o agronegócio o que gerou uma expansão das cidades e novos desafios para o planejamento da urbanização desses municípios.

O campo sul piauiense também é depositário dessas mudanças. Nos últimos anos a região apresentou uma importante expansão da agricultura moderna, especialmente com o crescimento das lavouras de soja e milho, mas também de outros produtos agrícolas, como o algodão e a cana-de-açúcar, que começam a despertar interesses de investidores que adquirem terras no Piauí. Tal fato revela um novo momento em que passa o estado e, em especial, os cerrados piauienses, destacando-se como região onde se consolida o agronegócio. Essa nova etapa de modernização da região se realiza tendo como suporte a apropriação das terras dos platôs planos nos denominados Gerais, amplos chapadões cobertos de vegetação de cerrado e onde se localizam as nascentes dos principais rios da região, como o Parnaíba, o Gurguéia, o Paraim e o Uruçui Preto. Por conta do acelerado desmatamento ocorrido nos últimos anos áreas dos Gerais, com o avanço das lavouras modernas, tanto o bioma e sua biodiversidade quanto as nascentes sofrem importantes prejuízos, mas também os espaços de usos camponeses que desaparecem velozmente diante da ocupação e da apropriação privada de antigas áreas onde a população local praticava diferentes usos.

A apropriação privada das terras dos Gerais e a emergência de um amplo mercado imobiliário no urbano e no rural representam uma das faces do processo de modernização em curso nos cerrados do sul do Piaú e do qual nos ocuparemos neste artigo. A escolha de tal fenômeno para análise, em uma região específica da hinterlândia brasileira, deve-se à possibilidade de revelar as contradições de um 
modelo pelo qual se estruturou o avanço da agropecuária moderna para as chamadas fronteiras agrícolas brasileiras cujo movimento, embora contraditório, mas não antagônico, colocou do mesmo lado Estado e capital, ambos direcionando suas ações a partir de uma racionalidade empresarial que ao mesmo tempo em que integrou o território nacional trouxe uma profunda fragmentação das comunidades e dos espaços locais.

Propõe-se, portanto, neste artigo, entender de que maneira a região dos cerrados piauienses se insere no novo contexto de modernização a partir da instalação de empresas hegemônicas, de produtores agrícolas modernos e de especuladores imobiliários, especialmente como se desenvolve o mercado de terras na região. Embora, este processo tenha se consolidado nos anos 1990, ele vinha se gestando desde os anos de 1970 quando os primeiros investidores se instalaram na região e adquiriram terras para o desenvolvimento de pretensos projetos de melhoramento da pecuária tradicional e de reflorestamentos utilizando-se para isso recursos públicos oriundos dos Fundos de Investimentos do Nordeste (FINOR). Neste sentido, buscaremos retomar esse percurso inicial de apropriação das terras dos Gerais dos cerrados piauienses, como fundamento para a compreensão dos desdobramentos seguintes do mercado de terras que está em pleno vapor na região.

\section{Os cerrados piauienses e as iniciativas governamentais direcionadas à aceleração dos processos de modernização}

As mudanças que se verificam atualmente nos cerrados piauienses possuem suas origens entre as décadas de 1960 e 1970, particularmente nessa última, quando ocorreram importantes investimentos públicos federais visando impulsionar a modernização do setor agropecuário de várias regiões brasileiras. No Nordeste, sobretudo, a preocupação era a de proporcionar condições para que a economia de áreas do interior da região, tradicionalmente de baixo rendimento produtivo, pudesse integrar-se ao mercado nacional, ou mesmo internacional, a partir das exportações de produtos primários: frutas, carne bovina etc. Foram criados, nesse sentido, dentre outros programas, o POLONORDESTE, o Projeto Sertanejo e o Programa de Irrigação do Nordeste. Além disso, foram disponibilizadas linhas de créditos da Superintendência para o Desenvolvimento do Nordeste (SUDENE) e do Banco do Nordeste (BNB) para projetos de reflorestamento e melhoramento da pecuária. 
No caso piauiense, dos recursos direcionados pelo POLONORDESTE para a modernização agropecuária, beneficiou-se principalmente a camada de médios e grandes proprietários rurais. Isso não ocorreu de maneira distinta na aplicação de recursos públicos no restante do Nordeste, o que confirma a intenção do programa de atingir especialmente esse segmento de produtores. De fato, o governo militar buscava orientar os recursos para aqueles proprietários de estabelecimentos que se imaginava em condições de acelerar a construção de um mercado nacional mais homogêneo. Observa-se, assim, que não somente as diretrizes do POLONORDESTE seguiam essas orientações, mas também as de programas executados em outras regiões, como as do POLOCENTRO, no Centro-Oeste. Dessa maneira, as estratégias visavam dirigir recursos para aqueles agricultores que pudessem responder mais rapidamente ao propósito definido pelo Estado brasileiro naquele momento, qual seja, o de aumentar as exportações a partir da produção agropecuária, para garantir o pagamento da divida externa e manter o equilíbrio da balança comercial, além de responder à pressão crescente por alimento decorrente do processo de urbanização em curso no país (OLIVEIRA, 2002).

Outros programas governamentais destinados ao Nordeste apresentaram objetivos semelhantes aos do POLONORDESTE. É o caso, por exemplo, dos Fundos de Investimentos do Nordeste (FINOR), administrados pela SUDENE, fundos que se derivaram do Mecanismo 34/18 criado em 1961, a partir do I Plano Diretor da própria SUDENE, cujo objetivo era disponibilizar investimentos públicos ao setor privado do Nordeste, através de incentivos fiscais. Uma parcela significativa dos recursos desse sistema (que passou posteriormente a se denominar FINOR) destinava-se prioritariamente para o setor rural, com destaque para a pecuária nordestina, cujo funcionamento ocorria com técnicas convencionais, como as de criar o gado solto alimentando-se de pastagens naturais. Dos projetos agropecuários aprovados pela SUDENE, entre os anos de 1965 e 1976, a pecuária bovina foi a que obteve maior participação (64,4\% do total dos projetos) no destino dos recursos (CARNEIRO, et al., 1984: 140). Isso comprova que a preocupação das políticas públicas direcionadas ao campo brasileiro, naquele momento, era a de acelerar os processos de modernização, partindo dessa atividade econômica, particularmente no Nordeste.

O direcionamento dos recursos financeiros destinados pelo FINOR Agropecuário, no Piauí, dirigiu-se, em grande medida, para o centro-sul do estado, com destaque para a área de cerrados, cujos fazendeiros locais e/ou de outras unidades 
da federação foram os principais beneficiados, obtendo financiamentos públicos facilitados através de linhas de créditos de bancos oficiais (Banco do Brasil e do Nordeste). Tais recursos teriam pretensamente como destino o melhoramento da capacidade produtiva das tradicionais fazendas de gado (aquisição e melhoramento do rebanho, plantação de pastagens etc.), projetos de produção agrícola, sobretudo de arroz, e, em menor volume, a formação de áreas de extrativismo.

Complementando o FINOR, foram disponibilizados também para os cerrados piauienses recursos advindos dos Fundos de Investimentos Setoriais (FISET) que, prioritariamente, destinavam-se a projetos de reflorestamento (principalmente de caju) ${ }^{1}$ recebendo financiamento do Banco do Brasil, via Instituto Brasileiro de Desenvolvimento Florestal (IBDF). A proposta era garantir que médios e pequenos empreendedores rurais pudessem desenvolver projetos geradores de renda e, ao mesmo tempo, aliar com a preservação ambiental. O que se verificou, todavia, foi o direcionamento dos recursos e do acesso à terra para apenas algumas empresas, principalmente de outros estados, as quais obtinham aprovação de vários projetos seus em detrimento de uma participação mais numerosa de produtores locais. A concentração de recursos financeiros e de terra advindos do FISET foi verificada nos municípios de Ribeiro Gonçalves e Uruçuí, conforme nos relata MONTEIRO (2002: 117), no que se refere aos efeitos dos projetos de reflorestamento instalados em tais municípios e os agentes favorecidos:

"O IBDF estabelece o limite de, aproximadamente, 100 hectares de terra para incentivar, via FISET, projetos de (re)florestamento. No entanto, os laudos de vistoria de acompanhamento do IBAMA (instituição que substitui o IBDF, a partir de 1989), provam a existência de diversos grupos de empresas, que possuem áreas superiores ao limite fixado. Por exemplo, o grupo empresarial que

administra os projetos instalados na Fazenda dos Gaúchos possui 32 projetos, totalizando 4.448,26 hectares de terras; o grupo empresarial que administra os projetos instalados na Fazenda Mafisa com 57 projetos para um total de 9.913,79 hectares de terra apropriada (ambos no município de Ribeiro Gonçalves); o grupo empresarial que administra os projetos da Fazenda Nova ou Bonita, em Uruçui, possui 58 projetos e uma área incorporada de 20.109

\footnotetext{
${ }^{1}$ O sul do Piaú foi, nos anos 1970 e 1980, a principal área do Brasil que abrigou projetos de reflorestamento com caju. Cerca de $108.871,52$ hectares, sendo que $88,90 \%$ correspondiam a áreas dos cerrados piauienses, destinaram-se aos projetos financiados para tal fim. Somente nos municípios de Uruçuí e Ribeiro Gonçalves as terras destinadas a reflorestamento com cultura de caju ocuparam uma extensão de 76.719,56 hectares. Essas áreas, em sua quase totalidade, foram transferidas posteriormente para projetos agropecuários modernos (MORAES, 2000: 210).
} 
hectares. Comparando-se o total de área dos estabelecimentos dos municipios de Ribeiro Gonçalves (457.539 hectares) e Uruçui (361.654 hectares), em 1985, com a área total dos 243 projetos financiados pelo FISET, que chega a 60.692,11 hectares, registra-se que essa última representa a ocupação de 7,4\% do território dos municipios. Este dado pode ser considerado aparentemente inexpressivo, mas quando se constata que três únicos grupos empresariais, como acima citados, possuem 34.471,05 hectares, representando $56,8 \%$, do total dos projetos incentivados, evidenciase o nível de concentração na aquisição de terras nos referidos municipios".

Esses projetos de reflorestamento no Piauí tiveram o mesmo fim dos de pecuária melhorada ou de outros associados à agricultura comercial; quase todos eles foram abandonados restando apenas em algumas áreas vestígios de grandes plantações de cajueiros, hoje, em muitos casos, substituídas por lavouras modernas. Os sucessivos governos piauienses contribuíram sobremaneira para a difusão de tais projetos no sul do estado e foram coniventes com o agravamento da concentração da estrutura fundiária na região, pois permitiram, através da Companhia do Desenvolvimento do Piauí (COMDEPI), o repasse de grandes extensões de terras públicas às empresas interessadas em aquisição de áreas para a execução de pretensos projetos agropecuários e de reflorestamento ${ }^{2}$. A participação da COMDEPI nas negociações de terras públicas repassadas às empresas representava uma estratégia do governo piauiense para despertar interesse dos investidores do agronegócio pela região dos cerrados e, ao mesmo tempo, garantir a existência de um mercado de terras na região.

A transferência do patrimônio fundiário público para o setor privado não trouxe ganhos financeiros para o estado, pois os preços cobrados nas transações possuíam

\footnotetext{
${ }^{2}$ As empresas que adquiriram terras são dos mais variados ramos de atividade, demonstrando que o interesse não era tanto o de desenvolver produtivamente projetos agropecuários, mas o de acesso a recursos públicos e, ao mesmo tempo, tomar posse de grandes extensões de terras. Em Ribeiro Gonçalves (Guimarães, 1988, apud Moraes, 2000) foram identificadas 30 empresas com suas respectivas áreas apropriadas no município, o que confirma a afirmação acima. Segue a relação de tais empresas e as extensões adquiridas em hectares: "CONFIANÇA Agro-Industrial (25.000); José Gomes da Silva (12.000), Agro-pecuária Guimarães S/A (25.000); CREMAQ - Reflorestamento e Agropecuária Ltda. (25.000); Transzero - Transportadora de Veículos Ltda. (24.736); MAFISA Agropecuária Ltda. (24.984); Serviços Agropecuários Ltda. (24.984); Alimentos Básicos do Piauí S/A - ABAPISA (25.000); Bastos Locadora Ltda. (22.553); PAISAGRO Ltda. (24.829); Serviços Agropecuários Ltda. (24.993); O.N.V. Participação e Administração S/A (05.961); O.N.V Agropastoril Ltda (05.929); Economisa Administradora de Imóveis Ltda (05.952); Economisa Reflorestamento Ltda. (05.959); Antonio José Siqueira (02.990); Estrela - Engenharia Ltda. (20.059); BRASIDIESEL S/A Comercial e Importadora (12.000); Expresso Caxiense S/A (12.000); Automecânica S/A Importação e Comércio (12.000); Eletro Tecnodiesel S/A (12.000); EMAFLOR - Empreendimentos Agroflorestais Ltda. (12.000); Oscar Tadeu Medeiros (1.571); Osacra Dantas Medeiros (1.918); ELETRON - Produtos Químicos Ltda. (14.087); TAOMINA - Agro Florestal Ltda. (23.580); Felipe
} 
mais um caráter "simbólico" do que exatamente o de aumentar os recursos financeiros dos cofres públicos, haja vista que a intenção era fomentar o fluxo de capital para uma unidade da federação que se pretendia inserir no curso da modernização retardatária. Mesmo que para isso precisasse abrir mão de suas riquezas. A forma como conduzida a ocupação dos cerrados piauienses com recursos financeiros federais subsidiados e com a participação de órgãos públicos estaduais, como a COMDEPI, foi em grande medida responsável pela a apropriação privada dos Gerais, em muitos casos de maneira irregular através da grilagem, por parte de um seleto grupo de pretensos investidores piauienses ou de grupos econômicos de outros estados, movimento que desencadeará posteriormente o mercado de terras, envolvendo a participação dos que receberam recursos financeiros da SUDENE para aquisição de grandes extensões de terras e que depois as revenderam a empresários e/ou produtores agrícolas do centrosul do país, sem, entretanto, realizarem qualquer atividade produtiva nelas, indicando que a intenção desses grupos era a de utilizá-las como uma reserva de valor. BANDEIRA (1993: 195), além de identificar em seu estudo tais estratégias utilizadas pelos agentes econômicos para a expansão do mercado de terras nessa região piauiense, apontou a importância dos recursos do FINOR e da participação da COMDEPI para a ocupação da região e o que resultou desse movimento, conforme esclarece:

\begin{abstract}
"Uma característica importante dos projetos do FINOR Agropecuário é a extensão, pois, poucas vezes, possuem áreas inferiores a 5.000 ha. No início, as terras eram adquiridas, sobretudo, na região dos cerrados, diretamente, ao governo estadual, a preços simbólicos, desde que era de interesse da administração, à instalação dos referidos projetos no Estado. A 'Companhia de Desenvolvimento do Piauí (COMDEPI)' era o órgão encarregado das negociações, mas face ao desconhecimento da quantidade de terras existentes e da situação em que se encontravam, podiam ser vendidas a mais de um projeto, culminando com a expulsão das pessoas que se encontravam em situação de posse. Em outras zonas, as terras eram adquiridas de proprietários e, via de regra, eram terras 'griladas'. Isto porque, grandes proprietários da região registravam imensas extensões de terra em seus nomes e, depois, as vendiam aos projetos, mesmo com a ressalva de que o preço da terra era baixo." (Grifo de Bandeira).
\end{abstract}

Depreende-se, portanto, que os programas governamentais destinados à modernização agropecuária e florestal dos cerrados piauienses, como ocorreu também 
em outras regiões do estado e/ou do semi-árido nordestino, não conseguiram atingir o objetivo proposto, pois a maioria dos projetos que teve implantação efetiva poucos deles alcançaram os resultados esperados, embora seja necessário reconhecer que em alguns casos os programas obtiveram avanços. Destaca-se, especialmente, o impulso ocorrido no melhoramento da atividade criatória que, com o acesso a tecnologias mais modernas, o setor alcançou certas melhorias em seu rebanho, sobretudo no que se refere a parte da genética do gado e também na implantação de novas pastagens para o gado, substituindo às naturais pelas plantadas. Estas mudanças, entretanto, se restringiram a algumas fazendas piauienses, especialmente na região sul do estado (BANDEIRA, 1993: 421). Em contrapartida, esse movimento desencadeou uma ampla apropriação fundiária e uma dinamização do mercado de terras que ganhou volume nas décadas que se seguiram ao inicio das políticas estatais mencionadas, de ocupação da região dos cerrados piauienses. Do comércio de terras passam a participar além dos agentes econômicos indicados acima, os novos investidores que chegam ao Piauí em busca de terras com potencialidade agrícola. Desse processo resultou também um aumento substancial da concentração de terra no sul do estado, expulsão de posseiros de suas terras e a proliferação de conflitos fundiários, indicando que essa é uma das novas faces da modernização agropecuária recente em que vive a região.

\section{A ocupação recente dos gerais sul-piauiense: a apropriação irregular da terra comunitária}

Os cerrados piauienses situam-se numa zona fisiográfica de transição, entre o semi-árido e a Amazônia. Pertencem à área nuclear dos cerrados brasileiros, na porção da bacia Maranhão-Piauí (AB'SÁBER, 2003). Os chapadões com vales encaixados, recobertos de vegetação de cerrado, campo cerrado, brejos e mata ciliar (SALES, 1997) compõem as principais características paisagísticas dessa sub-região dos cerrados nordestinos. Historicamente, os vales úmidos foram os preferidos pela população piauiense, principalmente porque foram os cursos d'água que conduziram o povoamento daquelas terras. Desde o início de sua inserção no processo de modernização capitalista, a partir da colonização portuguesa ou mesmo antes com as populações indígenas, a produção da vida dos piauienses dos cerrados passa a ser fundamentalmente nos vales próximos aos cursos d'água, seja para o desenvolvimento de atividades agrícolas, de criação de gado ou de extrativismo, seja para a formação 
das aglomerações urbanas. Os vales e a água constituíram-se como as referências mais importantes para a construção daquele território.

A pouca ocorrência de água na superfície dos platôs planos e a sua precária comunicação com os núcleos urbanos que se formaram na região, instalados freqüentemente próximos aos principais rios, impediam que os piauienses habitassem os domínios dos platôs planos, exceto nos vales intercalados, denominados de baixões, onde há água e terras férteis, e em muitos deles moram posseiros que sobrevivem de suas pequenas roças e do que podem extrair dos Gerais.

Os domínios dos platôs sempre representaram para os moradores dos cerrados piauienses lugares de usos complementares aos da vazante; eram pouco aproveitados para fins agrícolas ou de moradia, mas muito para a prática de uso comum. Caracterizavam-se como importantes reservas naturais onde se soltava o gado da população local (de fazendeiros a camponeses), que aproveitava das pastagens naturais em determinadas épocas do ano, ou serviam de lugar de caça, de extrativismo de lenha, de frutos e de plantas medicinais (ALVES, 2001). Por constituir-se predominantemente de terras devolutas, não cercadas, portanto, essas áreas formavam extensos descampados de matas nativas de cerrados. No contexto social local, as terras dos Gerais ou Chapadas (ou ainda Tabuleiros) significavam um lugar de vital importância para a manutenção do modo de vida das comunidades camponesas. Seu equilíbrio se mantinha pelo uso privado das roças, na vazante, e o que se podia aproveitar, sem qualquer impedimento, dos recursos existentes nos Gerais. A forma pela qual a população camponesa dos cerrados piauienses articulava o uso dos baixões e dos Gerais para garantir a manutenção da vida é evidenciada por MORAES (2000: 267), conforme nos relata:

“(...) os solos da chapada só passaram a ser propícios à prática da agricultura com as tecnologias geradas pela Revolução Verde. Esse terreno tampouco era tido pelos camponeses como lugar de agricultura. No entanto, a agricultura camponesa no ambiente dos cerrados, tomada como parte de um sistema produtivo em sentido mais amplo, supõe uma articulação essencial entre baixões $\boldsymbol{e}$ chapadas. Nesse sentido, se o baixão é o lugar do assentamento, da propriedade, da morada, da delimitação dos parentes e vizinhos, da nucleação em pequenas comunidades, a chapada é o mundo a perder de vista, terra de ninguém e, portanto, de todos - cujas funções são nem por isso menos básicas para a economia camponesa. Nesse sentido, era, no sistema antigo, segundo os camponeses, o lugar do uso em comum da terra voluntária, sem cercamento." (grifos de Moraes) 
A modernização contemporânea, com a instalação de novos agentes econômicos nos cerrados piauienses, a partir na década de 1970 em diante, significou uma importante metamorfose no uso das terras dos Gerais: de espaço de uso tradicional explorado comunitariamente pelas necessidades concretas de vida da população local para espaço privado destinado à agricultura capitalista moderna.

A recente ocupação dos platôs se define pelo uso essencialmente capitalista. As terras se tornam em si mercadorias colocadas no mercado imobiliário apresentando uma rápida valorização. Poucas delas são efetivamente cercadas, mas a configuração da propriedade particular aparece nitidamente delimitada e contrasta com o que havia anteriormente, amplos chapadões de cobertura de vegetação nativa. Neste sentido, o que era antes espaço de uso comunitário em áreas abertas sofreu metamorfose: às vezes, são as lavouras de soja, de milho, de algodão ou solos desnudos em imensos descampados que explicitam os limites da propriedade.

$\mathrm{Na}$ nova organização do espaço dos Gerais, a paisagem anterior desaparece rapidamente, no lugar onde havia vegetação original com grande variedade de espécies da flora e da fauna, instalam-se elementos da agricultura moderna. Os sistemas técnicos tornam-se os principais elementos presentes e auxiliam o ritmo da produção de mercadorias agrícolas: pivôs de irrigação; máquinas agrícolas fiscalizadas por satélites; grandes galpões capazes de armazenar milhares de toneladas de grãos monitorados sob rígido controle de qualidade; escritórios controlando em tempo real o preço das commodities nas principais bolsas mundiais; unidades de recebimento de grãos das grandes empresas instaladas em pontos estratégicos, e próximo delas um movimento intenso de caminhões despejando ou retirando produtos para as fábricas esmagadoras ou para os portos exportadores. Esse movimento torna-se revelador da insurgência de novos tempos vividos nos Gerais dos cerrados piauienses.

A apropriação privada e a presença das técnicas modernas nos Gerais reduziram significativamente as áreas de uso comunitário, cada vez menos disponíveis. Esse fato se reflete em toda a organização espacial e da vida da população local, inclusive no que diz respeito à ocupação dos vales. De acordo com que afirmamos anteriormente, os moradores dos cerrados aproveitavam as terras dos Gerais para, em determinadas épocas do ano, mandar suas reses, a fim de usufruírem as pastagens naturais; agora essa prática reduziu significativamente. Sem a disponibilidade de uso 
dos Gerais, os criadores se utilizam cada vez mais das terras do vale para a atividade pecuária, avançando sobre as de agricultura, principalmente a camponesa.

O depoimento que segue de um camponês, morador em terras de baixões do município de Bom Jesus, é revelador da mudança do direito costumeiro suprimido com a instalação de novos agentes econômicos, os quais passam a ocupar áreas onde antes havia outro tipo de uso:

\footnotetext{
"Não pode mais isso de colocar o gado na serra. Agora a lei (sic) garante o seguinte: que o gado tem que ser no cercado, tem que se criar preso para não entrá nos projetos lá da serra."

(Sr. Pedro, morador na posse Pirajá, no município de Bom Jesus, julho de 2005).
}

Outras formas de uso dos Gerais também decresceram nos últimos anos, limitando a ação dos camponeses. As matas nativas possuidoras de variados tipos de frutos, de plantas medicinais e de mel desaparecem numa velocidade alucinante diante do desmatamento provocado pelas lavouras modernas, as quais não deixam quaisquer vestígios de vegetação original. O mesmo ocorre com a caça e a madeira. Com a nova impossibilidade de usar essas terras para complementar sua alimentação ou para retirar de lá matéria-prima destinada a algumas atividades econômicas, como no caso, dentre outras, da madeira para produção de móveis, produziu impactos sócio-econômicos importantes em todo o conjunto da população camponesa local, revelando as novas potencialidades de crise que se anunciam, geradas pela modernização contemporânea.

As mudanças de uso chegam juntas com a expropriação dos camponeses moradores dos baixões. Essa população, em sua maioria posseira, habita essas áreas desde tempos imemoriais. Há registros na história piauiense da presença dela nos baixões desde o início da colonização portuguesa, cujas terras constituiriam o Piauí. Tais personagens foram aproveitados para tomar frente do processo de conquista de território para a coroa portuguesa, em áreas que antes pertenciam a distintas nações indígenas praticamente exterminadas pelos novos povoadores.

Os baixões representam para essa população excluída, a possibilidade de se manter com a sua família, produzindo apenas o necessário para sua sobrevivência e, eventualmente, comercializando o excedente nas feiras livres ou vendendo para algum comerciante das cidades locais. $\mathrm{O}$ isolamento desses domínios tornava-se um impedimento para o uso capitalista mais intenso, mesmo os tradicionais fazendeiros piauienses pouco se interessavam por eles, o que permitiu que levas de posseiros 
permanecessem nessas áreas, reproduzindo um modo de vida camponês até recentemente; em alguns casos, continuam, mas espremidos e pressionados pelos agentes do agronegócio que se instalam na região.

A presença da agricultura moderna vem alterando rapidamente esse quadro. Os camponeses dos baixões foram os primeiros a sofrerem o impacto da ocupação recente, pois no uso privado dos platôs planos também foram incluídas as terras de fundo de vale. Para a agricultura moderna, os baixões não apresentam, neste momento, importância produtiva, mas são utilizados para atender a legislação ambiental, pois é necessário reservar áreas de preservação permanente ${ }^{3}$. Como o empresário agrícola que adquire terras nessa região deseja retirar o máximo de vegetação das áreas nos platôs planos destinadas à produção agropecuária, sobram, então, as áreas de vales para cumprir as determinações legais ambientais.

Ao adquirir uma área de platôs onde existem também terras de baixões, o empresário ou o especulador imobiliário freqüentemente se posiciona contra a permanência de posseiros nessa área, requisitando a saída das famílias, seja através da coerção física seja tentando convencê-las a receber quantias em dinheiro (normalmente valores quase irrisórios) para deixar livres de ocupação humana.

Nos cerrados piauienses os casos recentes de expulsões de trabalhadores dos seus locais de moradias são incontáveis. Em Bom Jesus, o Sindicato de Trabalhadores Rurais do município recebeu, nos últimos anos, várias denúncias apontando para a expropriação de posseiros, além de verificar a ocorrência de conflitos entre grupos das próprias comunidades moradoras nos baixões, estimulados por especuladores fundiários interessados na aquisição das terras. Documentos contendo registros de depoimentos dos moradores dos baixões no sindicado daquele município indicavam uma acelerada expansão do comércio de terras, inclusive, com a participação de alguns posseiros que, estimulados pelo agente imobiliário, vendiam suas posses, produzindo prejuízo para os demais moradores dessas áreas.

\footnotetext{
${ }^{3}$ Pelo artigo 16 da MP no. 2.166-66, de 26 de julho de 2001, é necessário disponibilizar, como reserva legal, $20 \%$ da propriedade rural situada em área de floresta ou outras formas de vegetação nativa localizadas fora do perímetro da Amazônia Legal. No Piauí há um acordo entre governo e proprietário reservando $30 \%$ da propriedade para mata nativa (In: SEMAR-PI).
} 


\section{O avanço da grilagem e a formação do mercado de terra nos cerrados piauienses}

A grilagem nos cerrados piauienses é atualmente um grave problema, dado o volume de terras apropriadas de maneira irregular e o surgimento de conflitos agrários envolvendo posseiros, grileiros e produtores agrícolas modernizados. Essa questão, no entanto, tem suas raízes principalmente na década de 1970, como vimos, quando se instalam as primeiras empresas e/ou investidores mobilizados para a região com recursos da SUDENE. Em meados da década de 1970 (conforme relatos da população local, obtidos em trabalhos de campo), era comum a presença de representantes de empresas de outros estados, sobretudo nordestinos, em diligência pelos municípios dos cerrados piauienses à procura de terras para aquisição. Segundo apontam os moradores, quem se dispunha a vendê-las necessitava apenas da apresentação de um simples documento (uma carta, por exemplo) que comprovasse a presença da família na área. A "regularização" das mesmas era providenciada, posteriormente, pelos advogados das empresas.

Essa prática foi extremamente difundida no sul do Piauí e revela que uma das estratégias das pretensas empresas empreendedoras naquele momento era a de adquirir terras a baixo ou nenhum custo e utilizá-las para receber os benefícios governamentais, como os do FINOR agropecuário e do FISET. Isso porque somente poderiam ter acesso aos recursos de tais programas aquelas empresas que se apresentassem como detentoras de terra nas áreas onde fossem executados os projetos agropecuários e/ou de reflorestamentos. Nasce desse processo uma das ramificações da grilagem que se fortalece nos anos posteriores.

Naquela etapa de ocupação do sul do Piauí predominam grupos econômicos dos estados do Nordeste, mas também aparecem os primeiros empreendimentos "sulistas" nos cerrados nordestinos. Ambos amparados por políticas governamentais, como nos esclarece DINIZ (1984: 18);

\footnotetext{
"Os grupos econômicos são o segundo agente de penetração do capital [no Nordeste Centro-Ocidental Brasileiro]. Diferenciam-se dos agricultores individuais pelo suporte governamental de que dispõem, bem como pela violência de sua penetração. São, sobretudo, grupos nordestinos, mormente pernambucanos, amparados pelos incentivos da SUDENE e que tendem a ocupar e cercar grandes áreas. Aparecem também grupos extra-regionais, ligados ao sistema financeiro, como em Canto do Buriti, ou às vezes, acompanhando a migração individual, como em São Desidério, aonde começam a chegar grupos empresariais do Paraná”.
} 
Superada a fase dos projetos agropecuários e de reflorestamentos, ocorridos principalmente entre as décadas de 1970 e 80, inicia-se a fase de mobilização dos agricultores "sulistas" interessados no Piauí, atraídos pela possibilidade de adquirir terras a preços menores aos praticados em outras regiões do país. Há registros da instalação dos primeiros "sulistas" nos cerrados piauienses no final dos anos 1970, mas, a maior presença de migrantes de origem no sul do Brasil ocorre somente em meados dos anos 90, quando os sucessivos governos piauienses elaboraram políticas de incentivos para a atração de investidores do setor agropecuário para os cerrados piauienses. Nesse momento, expande-se o comércio fundiário nos municípios detentores de terras de platôs, sobretudo os localizados nas denominadas Serras do Uruçuí e do Quilombo. Apesar da aquisição de estabelecimentos abaixo de 1.000 hectares, o que predomina, entretanto, são extensões acima desse tamanho indicando o perfil do novo proprietário de terras que se instala no sul do Piaú. A pesquisa de Monteiro (2002) confirma (amparada em documentação fundiária dos cartórios das comarcas de Uruçuí e Ribeiro Gonçalves, em 2001) que a maioria dos negócios envolvendo aquisição de terras nesses dois municípios e no de Baixa Grande do Ribeiro (emancipado de Ribeiro Gonçalves em 1994) acontecia para os estratos de áreas acima de 1.000 hectares, conforme nos aponta a autora para o caso do município de Baixa Grande do Ribeiro:

"Ao longo de sete anos (1994 a 2000), são realizados, em Baixa Grande do Ribeiro, 122 negócios, o que corresponde à incorporação de 363.520,19 hectares. Chama atenção a predominância do número de negócios no estrato de área de 1.000 a menor de 10.000 hectares, com 44 transações (36,1\% do total), apropriando-se de uma área de 137.469,35 hectares, o que vale 37,8\% da área total negociada. Enquanto isso, o estrato de 10.000 e mais hectares conta com 13 transações, equivalendo a 10,6\% dos negócios, mas, incorporando 207.763,6 hectares, ou seja, 57,1\% da área total transacionada. Isto significa dizer que os dois maiores estratos de área 1.000 a menor de 10.000 hectares e 10.000 e mais hectares são responsáveis por 95\% do total da área transacionada, ou seja, o grande número de negócios é realizado, apropriando-se de vastas extensões de terras de Baixa Grande do Ribeiro".

A apropriação privada dessas terras foi coordenada pelo governo piauiense, responsável pelos programas de distribuição de lotes destinados a empresas e agricultores individualizados, geralmente de outros estados (MORAES, 2000). O objetivo do governo, em diferentes administrações, era o de fazer da região dos 
cerrados um celeiro de produção de grãos, principalmente nos platôs planos, onde havia grandes extensões, constituídas, predominantemente, de terras devolutas. A existência de áreas nessas condições representava uma marca importante na caracterização da estrutura fundiária dos municípios dos cerrados piauienses. Este fato é observado, por exemplo, nas informações da tabela 01 cujos números indicam a presença predominante, em alguns municípios do sul do Piauí, de terras devolutas. São elas a serem lançadas no mercado imobiliário, com envolvimento do governo (através da COMDEPI), dos fazendeiros locais, de grileiros, de especuladores e de investidores que chegam ao Piauí em busca de terras para produção ou para deixá-las como reserva de valor, a serem colocadas no mercado de terras na medida em que fossem sendo valorizadas.

O processo de ocupação de tais áreas foi extremamente conturbado, revertendo numa ampla transferência, de maneira ilícita, de terras de uso comunitário para as mãos de particulares, gerando descontrole na jurisdição da propriedade da terra. É possível encontrar atualmente nos cerrados piauienses, por exemplo, documentação fundiária atestando dois ou mais proprietários de uma mesma área. Ou seja, sobreposição de proprietários de posse de documentos cujas terras não existem, ou com documentação no "segundo ou terceiro andar", como costumam relatar os técnicos que investigam os problemas fundiários do sul do Piauí. Essa situação advém da construção de uma ampla rede de grileiros com experiências em apropriação de terras públicas concebidas em outras partes do país. A presença de falsificadores fundiários nos cerrados piauienses resulta da ramificação dessa rede, que se instala no Piauí disposta a usurpar um importante patrimônio de terras devolutas existentes nos municípios do sul do estado. 


\begin{tabular}{|c|c|c|c|}
\hline \multicolumn{4}{|c|}{$\begin{array}{l}\text { Tabela } 01 \text { - Área total do município e área total de terras devolutas de municípios } \\
\text { selecionados nos cerrados piauienses (em hectares) }\end{array}$} \\
\hline \multicolumn{4}{|c|}{\begin{tabular}{c|c|c|c} 
Município & $\begin{array}{c}\text { Área Total do } \\
\text { Município (ha) }\end{array}$ & $\begin{array}{c}\text { Área Devoluta } \\
\text { (ha) }\end{array}$ & $\begin{array}{c}\text { Em } \\
\text { porcentagem } \\
(\%)\end{array}$ \\
\end{tabular}} \\
\hline $\begin{array}{l}\text { Baixa Grande do } \\
\text { Ribeiro }\end{array}$ & $796.773,97$ & $615.638,97$ & 77,26 \\
\hline Bom Jesus & $568.558,13$ & $355.516,03$ & 62,29 \\
\hline Gilbués & $347.517,94$ & $143.287,04$ & 41,23 \\
\hline Ribeiro Gonçalves & $391.813,43$ & $192.424,03$ & 49,11 \\
\hline Santa Filomena & $536.890,12$ & $272.133,52$ & 50,68 \\
\hline Uruçuí & $854.231,83$ & $416.781,53$ & 48,79 \\
\hline Total do estado & $25.131 .152,16$ & $10.561 .277,79$ & 42,02 \\
\hline
\end{tabular}

Fonte: INCRA, 2003.

De acordo com ASSELIN (1982), acredita-se que a "escola" da grilagem, nessa nova etapa do avanço das relações capitalistas no Brasil, tenha nascido no oeste do Paraná, quando da ocupação daquela região. De lá, expandiu-se para outras regiões mais ao norte do País. É provável que a apropriação das terras da Amazônia Ocidental tenha acontecido com a participação de membros dessa "escola", e sua prática tenha se expandido também para os cerrados nordestinos.

A grilagem nos domínios dos platôs piauienses, ganha notoriedade na década de 1970, mas se intensifica em meados dos anos 80 em diante, quando essa sub-região dos cerrados nordestinos começa a despertar maior interesse de agentes do agronegócio. Os mecanismos de apropriação irregular da propriedade da terra são variados, embora exista uma "metodologia" semelhante nas ações. Os agentes econômicos que primeiro se instalam no Piauí nessa nova fase da modernização procuravam tomar posse de grandes extensões de terras, freqüentemente, estabelecendo alianças com grupos locais ou de estados vizinhos. Suspeita-se, também, de servidores do Instituto de Terras do Piauí (INTERPI) e da COMDEPI, os quais auxiliavam nos esquemas de corrupção, facilitando a titulação de terras devolutas para grupos privados. 
A participação dos cartórios dos municípios dos cerrados piauienses, entretanto, foi fundamental para a ampliação e a efetivação da rede de grilagem, acobertados, em muitos casos, por juízes de comarcas. Nos documentos disponíveis em órgãos públicos de fiscalização apontam como a apropriação de terra pública no sul do Piauí teve ampla participação de agentes públicos e privados.

Somente numa das diligências fiscalizatória nos cartórios de notas e registros de imóveis do sul do Piauí, em 2001, a Corregedoria do Estado encontrou graves irregularidades em quase todos eles, sobretudo no que se refere à transferência de terras devolutas para um seleto grupo de grileiros. Em Bom Jesus, por exemplo, um dos municípios onde a participação de grileiros foi intensa nos últimos anos, a referida fiscalização detectou que em apenas uma das falsificações de documentos fundiários houve apropriação privada de aproximadamente 97.000 hectares de terras devolutas, referendada sob a anuência da juíza daquela comarca naquele momento, conforme nos deixa claro o documento da Corregedoria:

\footnotetext{
"No Cartório do $2^{\circ}$. Ofício de Bom Jesus, encontramos o processo no. 43/75, de Demarcação e Divisão Amigável, lavrada às fls. 99, do livro no. 30, de 15/07/1989, em que, 'num acerto' entre os condôminos Ademar Queiroz Diógenes, Manoel Holanda Saldanha e José Soares de Holanda, apoiada em planta e memorial descritivo, firmado pelo agrimensor Elizio Pereira da Cruz, em desacordo com a lei, foram transformados, 860 (oitocentos e sessenta) braças e 539,00,00 (quinhentos e trinta e nove) hectares, em 97.170.00,00 (noventa e sete mil e cento e setenta) hectares. (...) Nesse ilegal e danoso procedimento demarcatório e divisório, infelizmente homologado, em 30/06/89, pela Juiza Maria do Rosário de Fátima Matos (...)."

(Correição extraordinária nos cartórios da comarca de Santa Filomena - PI - Corregedoria Geral da Justiça do Estado do Piauí. Abril de 2001).
}

O referido documento de fiscalização apontava outras situações em que ocorreu uma intensa ação de grileiros nos cerrados piauienses, com comprovação de que funcionários ou responsáveis pelos cartórios pertenciam à rede de falsários de terras devolutas. Apenas nos cartórios dos municípios de Santa Filomena, Gilbués e Bertolínia foram encontradas pelos corregedores, em meses concentrados de 1996 e de 1997, vinte e três (23) matrículas de imóveis e muitas averbações executadas irregularmente, envolvendo transferência de terras devolutas para o poder de grileiros, sendo o principal deles João Emídio de Sousa, procurador para a compra de terras no sul do Piauí destinadas a empresa Solo Sagrado Colonizadora e Negócios Ltda. Para 
efetivar a usurpação dessas terras, segundo consta no documento, tal grileiro contava com o auxílio de escreventes dos cartórios daquelas comarcas. Alguns dos registros expedidos nessas transações expõem falhas grosseiras, as quais indicam que os falsários pouco se preocupavam com possíveis revelações acerca das alterações nos registros da documentação, como fica evidente no referido relatório:

\begin{abstract}
"para a melhor doutrina, é considerado terras devolutas aquelas que não estejam incorporadas ao domínio privado, como acontece em muitos casos vistos, pois as próprias escrituras estão dizendo que os imóveis não registrados no registro imobiliário. Exemplos das muitas escrituras lavradas nos Cartórios do $1^{\circ}$. Ofício de Gilbués e de Bertolínia, referidas nestes autos, item IV, números 6 a 17 e 19 a 22. Nas referidas escrituras constam o número de registro eclesiástico, contudo, na época das referidas transações já vigorava a lei dos registros públicos, assim, antes de vender, seus proprietários deviam ter cuidado de registrar seus títulos, se é que possuíam. A regra está no artigo 227 da lei. Estranhamos que se possa, no Registro Eclesiástico, em duas folhas - 89v/90 - de um mesmo livro, e sob o mesmo no. - 454 - ter sido registrados o elevado número de proprietários e de propriedades, umas sem divisão e outras divididas e demarcadas. Só vendo pra crer!!!. (...) As retificações do registro imobiliário são feitas respeitando o disposto no artigo 213, da lei de registros públicos. Deve ser através de processo judicial, quando altera a descrição da área, sendo nula as re-ratificações procedidas em cartório, descritas no item IV, números 1, 6 a 17. No número 18 há um outro caso de alterar registro anterior, na descrição da área, sem o processo legal. Em todos eles há uma ilegalidade sobre a ilegalidade, ou seja, falsificaram o que já era falso"

(Correição extraordinária nos cartórios da comarca de Santa Filomena - PI - Corregedoria Geral da Justiça do Estado do Piauí. Abril de 2001).
\end{abstract}

As práticas golpistas apresentadas acima, empreendidas por grileiros profissionais, também são realizadas por indivíduos administradores dos cartórios dos municípios sul-piauienses. A participação comprovada de profissionais falsificadores de documentação pública no cartório de primeiro ofício do município de Gilbués, e em vários outros existentes nos cerrados piauienses, revela o comprometimento desses órgãos com a efetivação da propriedade privada da terra naquela área. Os métodos adotados pelos tabeliães envolvidos na falsificação dos registros fundiários consistiam em lavrar "escrituras públicas de compra e venda de imóveis ou de re-ratificação transformando ínfimos valores em cruzeiros de posse, em extensas áreas territoriais", conforme um dos exemplos que se segue: 


\begin{abstract}
"Escritura pública de re-ratificação, lavrada às fls 156, do livro 54, datada de 07/1997, em que o valor primitivo de Cr\$15,00 (quinze cruzeiros) de posse, foi convertido para 26.095,00,00 (vinte e seis mil, noventa e cinco) hectares, tendo como adquirente, João Emídio de Sousa Marques, e transmitentes, Antônio Lopes e outros."

(Correição extraordinária nos cartórios da comarca de Santa Filomena - PI - Corregedoria Geral da Justiça do Estado do Piaú́. Abril de 2001).
\end{abstract}

Somente no Cartório do $1^{\circ}$. Ofício de Gilbués foram identificadas trinta e duas (32) escrituras públicas de "re-ratificação", elaboradas entre 1997 e 2001, contendo esse "modus operandi", que totalizavam aproximadamente 258.464 hectares de terras devolutas transferidas ilegalmente para grileiros. Em apenas um dia, 02/02/2001, os corregedores identificaram a elaboração de dezoito dessas escrituras.

Outro grande usurpador de terra pública no sul do Piauí e oeste da Bahia, segundo acusação da Promotoria Pública dos respectivos estados, refere-se ao empresário e colonizador rural José Raul Alkimim Leão, baiano, proprietário da empresa Raul Leão - Agropecuária e Colonizadora (Agro-Pec), com sede em Brasília. Essa empresa organizou vários projetos de colonização nos cerrados nordestinos, principalmente para cooperativas do sul do Brasil. No Piauí, tal colonizador foi o responsável pela venda da gleba onde está instalado um grupo de famílias sulistas, numa área denominada Nova Santa Rosa, pertencente a uma gleba de 68.900 hectares nos platôs dos municípios de Palmeira do Piauí, Bom Jesus e Uruçui. A área constitutiva do Projeto "Nova Mogiana", concebido e executado pela Agro-Pec, empresa do ramo imobiliário, é mencionada nos documentos do Ministério Público Federal sob suspeita de ter sido adquirida pelo dito empresário através da ação de grilagem. Participam do Projeto "Nova Mogiana" reconhecidos empreendedores brasileiros do agronegócio, dentre outros, o ex-ministro da Agricultura do Governo Lula, Roberto Rodrigues; o Grupo Kenyti Okano, grande produtor rural da região de Ituverava, São Paulo; o empresário Ivoncy Brochmann Ioschpe, ex-presidente da Maxion, fabricante de tratores da marca Massey-Ferguson (Diário do Povo, 30/04/1999). Este último empresário torna-se um importante investidor nas terras dos Gerais piauienses, além da fazenda Vista $V e r d e^{4}$, é proprietário de várias outras

\footnotetext{
${ }^{4}$ A fazenda Vista Verde foi objeto de fiscalização do Ministério do Trabalho, em 2005, onde os fiscais do trabalho encontraram trabalhadores em situação análoga à de escravidão, como aparece no depoimento de um dos trabalhadores contratados temporariamente para exercer atividades na fazenda, conforme consta no relatório:

“(...) Neste diapasão, relata o trabalhador Aluizio Pedro dos Santos (fl.30) '(...) que foi contratado dia 08/01/2005 pela empresa através do sr. Chico Novo para trabalhar na catação de tocos; que
} 
fazendas na região e, em 2008, adquiriu o controle da empresa Insolo Agroindustrial, que se dedica a produção de arroz, soja, milho e algodão, e realiza gerenciamento agrícola e outros serviços para os novos produtores da região (Valor Econômico, 14/04/2011).

A maneira pela qual José Raul Alkimim Leão se apropriou das terras do Projeto "Nova Mogiana" consta nos registros da Corregedoria Pública piauiense:

\begin{abstract}
"No Cartório Único de Palmeira do Piauí, após as necessárias e percucientes investigações, além dos mesmos vícios encontrados em Bom Jesus e Cristino Castro, verificamos que por despacho prolatado pelo Juiz Plantonista, Osório Marques Bastos, no rosto de petição firmada por José Raul Alkimim Leão, e pelo seu advogado, Airton Teixeira Gomes, se a inafastável intervenção do Ministério Público, portanto, em desacordo com a lei, 1.493,00,00 (hum mil e quatrocentos e noventa e três) hectares foram transformados em 68.900,00,00 (sessenta e oito mil e novecentos) hectares, indevidamente averbados na matrícula no. 1.748 daquela serventia. Após a indevida, ilegal e citada averbação, o senhor José Raul Alkimim Leão, adquirente do imóvel em alusão, através de sucessivas transações, o vendeu para terceiros, restando, apenas dos 68.900,00,00 (sessenta e oito mil e novecentos) hectares, uma área remanescente de aproximadamente 4.000,00,00 (quatro mil) hectares." (Correição extraordinária nos cartórios da comarca de Santa Filomena - PI - Corregedoria Geral da Justiça do Estado do Piauí. Abril de 2001).
\end{abstract}

Prestigiado pelos grandes empresários rurais brasileiros, como ele próprio se promove numa reportagem paga no jornal piauiense "Diário do Povo" (30/04/1999), o colonizador José Raul Alkimim Leão atua no segmento do mercado imobiliário rural desde a década de 1980, inicialmente no oeste da Bahia, e, mais recentemente, no sul do Piauí. Diz ser proprietário de mais de 200 mil hectares de terra no Chapadão de Uruçuí, onde ocorrem instalações de fazendas destinadas à agricultura moderna. Para o Ministério Público, entretanto, as terras em poder de tal colonizador superam os 300.000 hectares, conforme menciona novamente o documento:

levanta(va) às 4 horas da manhã faz o almoço e vai para o campo; que, às vezes, caminha até 01 hora para chegar ao local de trabalho; que trabalha, mais ou menos, até o meio dia; que descansa e almoça em mais ou menos 01 hora; que, depois de comer, retorna novamente ao trabalho e vai até, mais ou menos, as 17h; que trabalha nesta jornada todos os dias, inclusive nos domingos e feriados; que não recebeu botas, nem luvas e nem chapéus; que trabalha de chinelo e com as mãos nuas; que os espinhos dos tocos de vez em quando furam suas mãos e seus pés”. In: Relatório de Fiscalização (Fazenda Vista Verde - Manoel Emidio - PI). Ministério do Trabalho e Emprego, novembro/2005. 


\begin{abstract}
"Ressalte-se que José Raul Alkimim Leão, é o mesmo que se diz adquirente de uma área de 107.660,00,00 (cento e sete mil, seiscentos e sessenta) hectares de terras, em Avelino Lopes, e que, através de procedimentos ilegais e condenáveis, conseguiu a averbação de 68.900,00,00 (sessenta e oito mil e novecentos) hectares, em Palmeira do Piaui. Vê-se, pois, que se somando a área por ele adquirida e parte já ilegalmente averbada, perfaz um total de 312.560,00,00 (trezentos e doze mil e quinhentos e sessenta) hectares".

(Correição extraordinária nos cartórios da comarca de Santa Filomena - PI - Corregedoria Geral da Justiça do Estado do Piauí. Abril de 2001).
\end{abstract}

As empresas do agronegócio, dentre elas as colonizadoras, são apontadas como os principais agentes promotores da rede de grilagem das terras no sul do Piaú, fenômeno que vem sendo alvo, atualmente, de investigação dos ministérios públicos, estadual e federal; da Assembléia Legislativa do Piauí; da Polícia Federal; e, até mesmo, da Polícia Internacional (Interpol). A participação dessa última se deve a suspeita da existência de uma máfia estrangeira interessada em se apropriar de terras devolutas dos cerrados piauienses (Jornal Meio Norte, 19/06/2005).

Após a efetivação de ampla apropriação irregular de terras devolutas que continua ainda em pleno vapor, surge nos últimos anos um intenso comércio imobiliário, principalmente envolvendo terras dos platôs planos cuja valorização econômica elevou os lucros dos especuladores. A apropriação privada das terras de uso comunitário não se restringe apenas a empresas do ramo imobiliário, como as colonizadoras (muitas delas remanescentes de empresas beneficiadas com recursos da SUDENE), mas se amplia para outros agentes econômicos: revendedoras de maquinários e equipamentos agrícolas, cooperativas, bancos, agricultores autônomos, etc. O negócio com terra, circundando esses distintos ramos de atividades econômicas, denuncia que a terra transformada em mercadoria constitui um dos pilares do processo de acumulação capitalista, estruturadores da nova fase da modernização piauiense.

O acompanhamento do preço do hectare de terra nos últimos anos nos principais municípios de produção de grãos, como Uruçui e Bom Jesus, permite constatar uma grande valorização dessas áreas, principalmente as dos platôs, preferidas porque são mais propícias para o desenvolvimento da agricultura mecanizada.

O preço da terra nos cerrados piauienses teve uma importante ascensão nos últimos anos. Embora ocorra diferenciação no preço das terras dos Gerais, Bom Jesus e 
Uruçui possuem as áreas que obtiveram mais valorização por conta desses municípios tornarem-se os principais produtores de grãos do estado e pólos concentradores de empresas e produtores agrícolas modernos. Em áreas localizadas nas proximidades das unidades de recebimento de grãos das grandes empresas ou da planta de processamento da Bunge Alimentos, em Uruçui, ou ainda nos ramais dos principais corredores rodoviários da região, o hectare de terra beneficiada ou que já possui alguma infra-estrutura (energia elétrica, proximidade de estradas vicinais, georeferenciamento, etc) pode custar 5.000,00 reais. $\mathrm{O}$ hectare de terra bruta nos municípios do sul do Piauí, entretanto, possui um preço médio de 500,00 reais ou aproximadamente 18 sacas de soja de 60 quilos $^{5}$. Estas últimas são utilizadas, frequentemente, como unidades de referência para a comercialização de terras nos cerrados piauienses. Embora se considere estes valores ainda muito abaixo se comparado aos de outras regiões brasileiras de produção agrícola moderna, onde o hectare pode custar acima de 10.000 reais, a terra nos cerrados piauienses apresentou significativa valorização. Antes de chegar ao preço que se cobra atualmente pelo hectare de terra nos Gerais, nos anos 1990, pagava-se por uma área de mesmo tamanho aproximadamente dez sacas de soja. No final dos anos 1980, essa mesma unidade de área custava uma saca de soja. Antes disso, porém, em meados dos anos 1980, as terras planas dos platôs eram bem menos monetarizadas, costumava-se dizer, na região, que o hectare poderia ser adquirido pelo "preço equivalente ao de uma cerveja" (ALVES, 2006: 197).

Apesar de sua recente valorização, o preço da terra continua sendo o principal atrativo para os investidores agropecuários que se deslocam para os cerrados piauienses. Nesse comércio, predominam segmentos associados ao capital nacional representado, sobretudo, por grupos de empresas de distintos setores econômicos, e por produtores agrícolas de várias regiões do Brasil, particularmente os oriundos de outras fronteiras agrícolas do país mais consolidadas. Recentemente, entretanto, houve um significativo aumento de investidores estrangeiros para aquisição de terras, empresas e fundos de investimentos, sejam grupos associados ao capital nacional ou independentes, inclusive representantes de Estados nacionais, como chineses e japoneses. Terras destinadas à produção de alimentos, de biocombustíveis, mas

\footnotetext{
${ }^{5}$ Referência utilizada para o comércio de terras na região, uma saca de soja (60 quilos) equivale, em média, a R \$ 40,00, valor referente ao ano de 2011 para os municípios a região dos cerrados nordestinos.
} 
também como reserva de valor. Esse movimento demonstra que esta será uma nova etapa do processo de modernização em curso nos cerrados piauienses.

\section{Considerações Finais}

O impulso a produção de mercadorias agrícolas nos cerrados piauienses vem produzindo importantes mudanças naquela região. Tal movimento comandado por agricultores modenos e por empresas hegemônicas do setor de alimentos ganha destaque nas últimas décadas e já impõe uma nova organização da produção e nasformas de vida da população local, especialmente no que diz respeito da transformação de seus espaços de reprodução da vida. O tempo único ditado pela economia de mercado vem se sobrepondo às outras formas de relações que não seguem os parâmetros exclusivamente fundados no automovimento do dinheiro.

Na nova etapa de ocupação dos cerrados piauienses aparece como uma das suas facetas a apropriação privada de importantes parcelas de terras que passam a fazer parte de um crescente mercado imobiliário na região. Transformadas em mercadorias valiosas na medida em que avança o processo de modernização, elas se constituiam anteriormente em áreas de uso comum aproveitadas pela população local para complementar a sua sobrevivência. Os domínios dos platôs planos, denominados de Gerais, são os de maior interesse do capital e que agora se transformam em lugares com presença da agricultura capitalista moderna ou em áreas de especulação imobiliária, sob o controle de grandes investidores do agronegócio. A configuração desse mercado terras que embora ganhe importância a partir dos anos 1990, tem sua constituição a partir especialmente da década de 1970 quando ocorre um primeiro movimento para a apropriação privada das terras devolutas da região, na maioria das vezes de maneira irregular, através da grilagem, por pretensos investidores de projetos agropecuários e de reflorestamentos, utilizando-se de recursos públicos disponibilizados pela Sudene. Desse processo resulta uma ampla transferência de terras públicas para a posse de especuladores, colocadas posteriomente no mercado imobiliário.

Desse avanço do capital e da privatização das terras do Gerais e de seu crescente uso pela lavoura moderna ampliando o desmatamento e reduzindo a 
biodiversidade do bioma, também resultou na supressão do direito costumeiro de uso comunitário da terra realizada pela população local. Esses espaços que antes eram usufruídos comunitariamente pela população sem que se necessitasse remunerar alguém pelo seu uso, porque ali existiam riquezas naturais fundamentais para reprodução da vida disponíveis a todos, transformaram-se em áreas de posse de um seleto grupo de especuladores e produtores rurais que imprimem uma outra lógica, marcada pelo uso delas para produção de mercadorias destinadas ao grande mercado consumidor de commodities agrícolas ou para a especulação.

A apropriação dos platôs seguindo essa nova lógica representa, neste sentido, a sentença final sobre o direito costumeiro praticado pela população local nessas áreas desde tempos imemoriais, restando-lhe agora como alternativa lançar-se ao mercado de trabalho assalariado em condições precarizadas, especialmente nas fazendas modernas que se expandem pela região, ou migrar para o urbano onde se depara com novas formas de exclusão.

\section{Bibliografia}

AB'SÁBER, Aziz Nacib. Os Domínios de Natureza no Brasil: Potencialidades Paisagísticas. São Paulo: Ateliê Editorial, 2003.

ALVES, Vicente Eudes Lemos. Formação Territorial Sul Piauiense: Modernização Agropecuária e Resistência Camponesa. São Paulo: Universidade de São Paulo, Faculdade de Filosofia, Letras e Ciências Humanas, Departamento de Geografia, Dissertação de Mestrado, 2000.

ARAÚJO, Márcia Regina Soares. Expansão da Fronteira Agrícola nos Cerrados Piauienses, (des)Territorialização e os Desafios para o Desenvolvimento Territorial: o Caso do Municipio de Bom Jesus. Teresina: Universidade Federal do Piauí/PRODEMA/TROPEN, Dissertação de Mestrado, 2006.

ASSELIN, Victor. Grilagem, Corrupção e Violência em Terras do Carajás. Petrópolis: Vozes, 1982.

BANDEIRA, Willian J. Os Programas e Projetos Governamentais e seus Efeitos sobre a Estrutura Agrária Piauiense no Pós-70. Campinas: Universidade Estadual de Campinas, Instituto de Economia, Tese de Doutorado, 1993.

CARNEIRO, Ricardo; SAMPAIO, Y. \& GOMES, G. M. "Os Programas de Desenvolvimento Rural: Região Nordeste". In PIMES (SUDENE) Desigualdades Regionais no Desenvolvimento Brasileiro, v.3, Recife: SUDENE, 1984, pp.87-245.

CORREGEDORIA Geral da Justiça do Estado do Piauí. Correição (Fiscalização) Extraordinária nos Cartórios da Comarca de Santa Filomena. Teresina: abril, 2001 (texto mimeo). 
COMISSÃO Pastoral da Terra (CPT). Conflitos de Terra por Estado - Brasil, 19972003. Disponível em: http://www.cptnac.com.br

DINIZ, José A. "Modernização e Conflito na Fronteira Ocidental do Nordeste". In Revista Geonordeste, ano I, n 1 , Aracaju, 1984, pp. 12-20.

DINIZ, José A.F. Geografia da Agricultura. São Paulo: Difel, 1984.

MARTINS, José de Souza. Fronteira: a Degradação do Outro nos Confins do Humano. São Paulo: Hucitec, 1997.

MARTINS, José de Souza. O Cativeiro da Terra. São Paulo: LECH, 1981.

MONTEIRO, Maria do Socorro L. Ocupação do Cerrado Piauiense: Estratégia Empresarial e Especulação Fundiária. Campinas: Universidade Estadual de Campinas, Instituto de Economia, Tese de Doutorado, 2002.

MORAES, Maria Dione de C. Memórias de um Sertão Desencantado; Modernização Agrícola, Narrativas e Atores Sociais nos Cerrados do Sudoeste Piauiense. Campinas: Universidade Estadual de Campinas, Instituto de Filosofia e Ciências Humanas, Tese de Doutorado, 2000.

OLIVEIRA, Ariovaldo U. de. “A Geografia Agrária e as Transformações Territoriais Recentes no Campo Brasileiro". In CARLOS, A. F. A. (org.). Novos Caminhos da Geografia. São Paulo: Contexto, 2002, pp.63-110.

OLIVEIRA, Ariovaldo U. de. "BR - 163 Cuiabá - Santarém: Geopolítica, Grilagem, Violência e Mundialização". In TORRES, Maurício (org.). Amazônia Revelada: os Descaminhos ao Longo da BR - 163. Brasília: CNPq, 2005, pp. 60-169.

OLIVEIRA, Ariovaldo Umbelino de. "Os Mitos sobre o Agronegócio no Brasil". In Revista Sem Terra, ano VI, $\mathrm{n}^{\mathrm{o}}$ 24, mai-jun, 2004. Disponível em: http://www.mst.org.br

PRADO JR., Caio. Formação do Brasil Contemporâneo. São Paulo: Brasiliense, 1965.

SALES, Marta C.L. Estudo da Degradação Ambiental em Gilbués - PI: Reavaliando o 'Núcleo de Desertificação'. São Paulo: Universidade de São Paulo, Faculdade de Filosofia, Letras e Ciências Humanas, Departamento de Geografia, Dissertação de Mestrado, 1997. 